\title{
Effect of cimetidine on enzyme inactivation, bile acid precipitation, and lipid solubilisation in pancreatic steatorrhoea due to cystic fibrosis
}

\author{
P L ZENTLER-MUNRO, D R FINE, J C BATTEN, AND T C NORTHFIELD \\ From the Norman Tanner Gastroenterology Unit, St James' Hospital, The Brompton Hospital, and \\ Department of Medicine II, St George's Hospital Medical School, London
}

SUMmARY In pancreatic steatorrhoea, both $\mathrm{pH}$-dependent bile acid precipitation and enzyme inactivation may limit the efficacy of pancreatic enzyme supplements and both may be preventable by addition of cimetidine. To separate these effects we compared postprandial jejunal aspirate from eight adults with steatorrhoea due to cystic fibrosis on three randomised treatment regimens (pancreatin, cimetidine, and both together). We also compared the results with those of previous studies of patients on no treatment, and of healthy subjects. On pancreatin $60 \%$ of the test meal entered the jejunum at $\mathrm{pH}<5$ compared with $17 \%$ in health. Lipase concentration and lipolysis increased over the values on no treatment $(14.2$ vs $4.4 \mathrm{U} / \mathrm{l}, \mathrm{p}<0.01$; $16 \%$ vs $11 \%, \mathrm{p}<0.02)$ but bile acid precipitation was not reduced (38\% vs $27 \%$, NS), and aqueous-phase lipid concentration decreased $(6.7$ vs $8.6 \mathrm{mM} / \mathrm{l}, \mathrm{p}<0.05)$. On cimetidine, bile acid precipitation fell $(19 \%$ vs $38 \%, \mathrm{p}<0.05)$; although lipase concentration and lipolysis were lower than on pancreatin $(4.8 \mathrm{U} / 1$ vs $14.2 \mathrm{U} / \mathrm{l}, \mathrm{p}<0.01 ; 9 \%$ vs $16 \%, \mathrm{p}<0.01)$ lipid solubilisation increased $(8.8$ vs $6.7 \mathrm{mM} / 1, \mathrm{p}<0.05)$. On the combination, there was a marked improvement $(\mathrm{p}<0.02)$ in lipid solubilisation $(18.3 \mathrm{mM} / \mathrm{l})$, reflecting the improvement both in lipase $(38.4 \mathrm{U} / \mathrm{l})$ and lipolysis $(24 \%)$, and in bile acid precipitation $(5.6 \%)$. We conclude that the efficacy of pancreatin is limited by $\mathrm{pH}$-dependent bile acid precipitation in addition to enzyme inactivation. The action of cimetidine in improving the efficacy of pancreatin depends on prevention of both these effects.

Steatorrhoea caused by pancreatic exocrine insufficiency is an unpleasant symptom, and often also leads to severe malnutrition and malabsorption of fat-soluble vitamins, ${ }^{1}$ essential fatty acids $^{2}$ and bile acids. ${ }^{34}$ Pancreatic steatorrhoea can pose a difficult therapeutic problem because treatment with pancreatic enzyme supplements (pancreatin) often fails to restore fat absorption to normal. ${ }^{5}$ It is a particular problem in patients with pancreatic insufficiency due to cystic fibrosis ${ }^{6}$ who may take 10 or more tablets per meal without relief of their steatorrhoea. Such high doses can lead to hyperuricaemia ${ }^{7}$ and renal damage $^{8}$ attributable to the high purine content of pancreatin.

The failure of pancreatin to correct fat malabsorption is usually attributed to inactivation of its enzyme content in the stomach, as the three major

Address for correspondence: Dr T C Northfield, Department of Medicine II, St George's Hospital, Cranmer Terrace, London SW17 0RE.

Received for publication 29 October 1984 pancreatic enzymes - lipase, trypsin and amylase are irreversibly inactivated by acid. ${ }^{9}$ In patients with pancreatic steatorrhoea about $90 \%$ of the enzyme content of pancreatin is inactivated in the stomach, so that even with a large dose duodenal enzyme activities do not achieve $10 \%$ of the normal concentrations, ${ }^{10}$ the minimum required for normal digestion. ${ }^{11}$ Enteric coated tablets ${ }^{12}$ and microspherules, ${ }^{13}$ designed to protect the enzymes during their passage through the stomach, do not abolish steatorrhoea, although they reduce it in some patients. This suggests that mechanisms other than gastric inactivation must contribute to the failure of pancreatin therapy.

In pancreatic insufficiency, bicarbonate as well as enzyme secretion is reduced. ${ }^{14}$ We have recently shown, in a study of 12 untreated adults with steatorrhoea due to cystic fibrosis, ${ }^{15}$ that this leads to postprandial jejunal hyperacidity: $40 \%$ of a test meal entered the jejunum at a $\mathrm{pH}$ below 5 , at which $\mathrm{pH}$ bile acids precipitated out of aqueous 
solution leading to a reduction in aqueous phase bile acid concentration. Lipid solubilisation, already reduced because of lipase deficiency, was further reduced in samples of $\mathrm{pH}<5$ because of this reduction in aqueous phase bile acid concentration. Treatment with pancreatin might be expected to improve lipolysis but not jejunal hyperacidity; ${ }^{10}$ $\mathrm{pH}$-dependent bile acid precipitation might therefore continue to limit lipid solubilisation. Protonation of fatty acids at $\mathrm{pH}<6$ increases their partitioning into the oil phase ${ }^{16}$ and might also limit lipid solubilisation during treatment.

Enteric coating of pancreatin probably fails because it delays dissolution of the tablet in the hyperacidic jejunum ${ }^{17}$ and because it cannot prevent bile acid precipitation and fatty acid partitioning. Raising the postprandial $\mathrm{pH}$ of the gastric and duodenal contents, on the other hand, might improve the efficacy of pancreatin by preventing both intragastric enzyme inactivation, and intrajejunal bile acid precipitation and fatty acid partitioning.

The aim of our study was therefore to determine whether gastroduodenal neutralisation would prevent these three $\mathrm{pH}$-dependent effects, and which would contribute most to any improvement in lipid solubilisation. We studied adult cystic fibrosis patients, who tend to have particularly resistant steatorrhoea ${ }^{6}$ perhaps because pancreatic bicarbonate secretion is even lower ${ }^{18}$ and gastric acid secretion often higher ${ }^{19}$ than in other forms of chronic pancreatitis. We again used the technique of acid inactivation to arrest lipolysis in jejunal aspirate which we have shown to be simpler and more accurate than the conventional heat inactivation technique. ${ }^{20}$

\section{Methods}

\section{SUBJECTS}

Eight adult patients with steatorrhoea due to cystic fibrosis were studied, four male and four female, average age 21 years (range 13-29 years), average weight $51 \mathrm{~kg}$ (range $45-61 \mathrm{~kg}$ ). These subjects were selected from the 12 already studied on no treatment, ${ }^{15}$ on the basis that they were fit and willing to undergo further intubation. They were not selected for the severity of their steatorrhoea. None had clinical evidence of liver disease. All subjects gave informed consent according to the declaration of Helsinki. Women with regular periods were studied within 10 days of menstruation.

\section{DESIGN OF EXPERIMENT}

Postprandial jejunal aspiration was carried out on three different treatment regimens: (i) pancreatin alone (P); (ii) cimetidine alone (C); (iii) pancreatin + cimetidine $(\mathrm{P}+\mathrm{C})$. Each regimen was given on a separate occasion separated by at least two weeks, in random order according to a Latin square design. In three subjects, who lived far from the hospital, the studies had to be done on three successive days; in order to avoid depleting their bile acid pool, all aspirate not required for analysis was returned to the patient at the end of the study, so that after the second study a maximum of only $180 \mathrm{ml}$ of aspirate $(1.8 \mathrm{mM}$ of bile acid) had been removed for analysis. This represents less than $10 \%$ of the bile acid pool size measured in a group of untreated children with cystic fibrosis in whom bile acid pool size was known to be markedly reduced. ${ }^{21} \mathrm{~A}$ constant diversion of at least $20 \%$ of the enterohepatic recirculation of the bile acid pool is required to reduce bile acid secretion. ${ }^{22}$

\section{MEDICATION AND MEAL}

Pancreatin was given with the test meal as seven Pancrex V capsules (specially formulated to be equipotent to Pancrex V Forte tablets - Paines and Byrne Ltd) containing $39000 \mathrm{BP}$ units of lipase in total. Cimetidine was given in a total dose of $400 \mathrm{mg}$ in aqueous solution; in four patients it was administered as an intravenous injection of $100 \mathrm{mg}$ immediately before the test meal followed by an intravenous infusion of $100 \mathrm{mg} / \mathrm{h}$ for the three hours of the test. In the other four patients poor veins prevented venepuncture and the entire dose was instilled via the aspiration tube into the jejunum 40 minutes before the test meal. There was no difference in gastric or duodenal $\mathrm{pH}$ between these two groups. The Lundh-type test meal (40 g dextrose, $15 \mathrm{~g}$ skimmed milk powder, $2.5 \mathrm{~g}$ polyethylene glycol 4000 (PEG) dissolved in $230 \mathrm{ml}$ water and thoroughly mixed with $18 \mathrm{~g}$ corn oil) was drunk recumbent within four minutes. On the cimetidine regimens, $2 \mathrm{~g}$ sodium bicarbonate was added to the test meal ( $\mathrm{pH} 7.6)$ so as to be certain of maintaining duodenal $\mathrm{pH}$ above 6 , because in an early study of two patients with alcoholic pancreatitis only the addition of alkali to metiamide achieved duodenal neutralisation. ${ }^{23}$ On the pancreatin alone regimen, no alkali was added to the meal ( $\mathrm{pH} \mathrm{6.6)}$ ) and cimetidine placebo solution was infused or instilled as appropriate.

\section{INTUBATION AND ASPIRATION PROCEDURES} These have been described and referenced previous$1 y^{20}$ and are given here in abbreviated form. After an overnight fast a double lumen tube was passed to the duodenojejunal flexure under fluoroscopic control, and the patient drank the test meal after appropriate medication. As much jejunal content as 


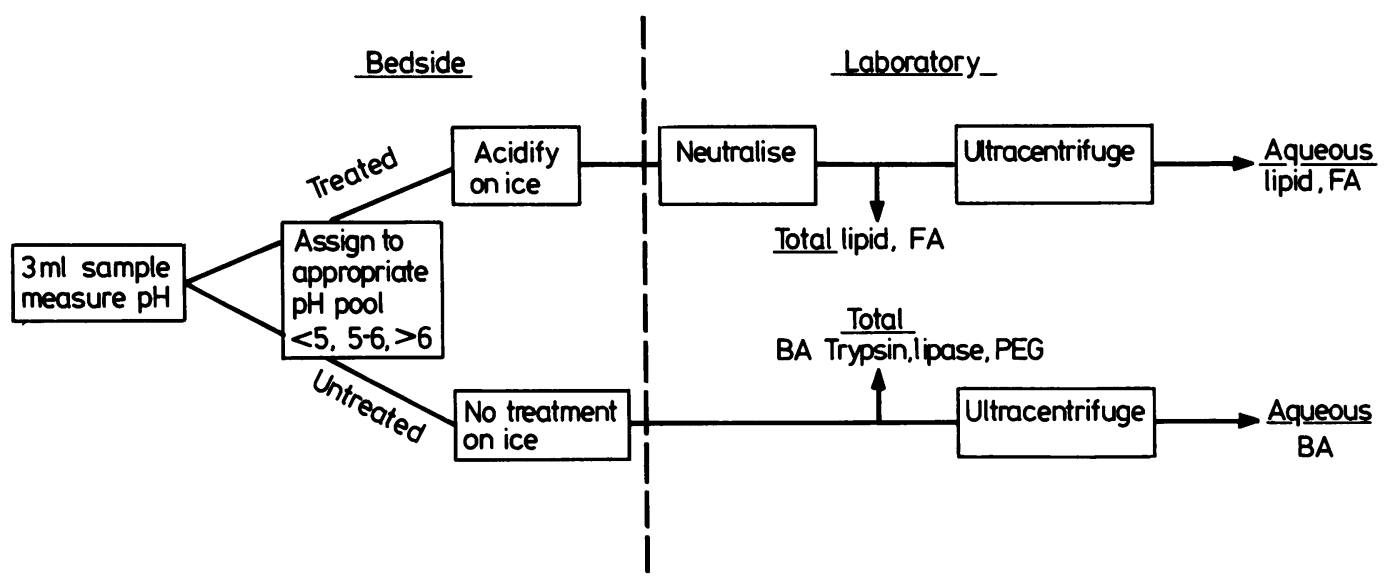

Fig. 1 Processing of jejunal aspirate samples.

possible was collected continuously by syphonage and syringe aspiration into ice cooled $10 \mathrm{ml}$ measuring cylinders. The $\mathrm{pH}$ of each $3 \mathrm{ml}$ sample was measured immediately with a glass electrode. Half of each sample was adjusted to $\mathrm{pH} 3$ immediately with acid to inactivate lipase,$^{20}$ and the treated and untreated samples pooled separately according to their measured $\mathrm{pH}(<5,5-6,>6)$ and time (1st, 2nd, 3rd hour) as described previously (Fig. 1).

In the first four subjects a triple lumen tube was used; the third lumen ended in the gastric atrum and allowed postprandial gastric samples to be aspirated, their $\mathrm{pH}$ measured, and returned to the stomach every 15 minutes. Gastric $\mathrm{pH}$ remained above 7 throughout the test in four patients on each cimetidine regimen, compared with below 2 on pancreatin alone. Checking gastric $\mathrm{pH}$ therefore appeared to be unnecessary; as it added to discomfort the third lumen was not used in the last four patients.

LABORATORY PROCEDURES (as described and referenced previously ${ }^{20}$ )

Each treated pool was analysed for total saponifiable lipid and fatty acid concentration after restoration to its original $\mathrm{pH}$, and each untreated pool for bile acid, trypsin, lipase and PEG concentrations. All pools were ultracentrifuged overnight at 100000 $g$, and each aqueous phase removed in its entirety, mixed and analysed for lipid and fatty acid (treated pools) and bile acid (untreated pools).

MATHEMATICAL ANALYSIS (as described previously $^{20}$ )

In each subject the $\mathrm{pH}$ pools were compared after mathematically pooling the separate hourly pools for each $\mathrm{pH}$, taking account of the volume of each pool and converting $\mathrm{pH}$ values to hydrogen-ion concentrations before pooling. The three hourly pools were compared after similarly pooling the separate $\mathrm{pH}$ pools for each hour. The overall mean was calculated by pooling all the separate pools. Statistical comparison of the pools within treatments and of the overall means between treatments was performed by the Wilcoxon's signed rank test for paired samples. Differences significant only at $10 \%$ $(0.05<\mathrm{p}<0 \cdot 10$, two- tailed test $)$ have been indicated in the results in order to avoid the possibility of a type II error $(n=8)$ where differences were large. Data are expressed as mean \pm SEM.

\section{Results}

The results on pancreatin alone were compared with those of the same eight patients on no treatment, taken from our previous study of 12 cystic fibrosis patients on no treatment $;^{15}$ although the studies on no treatment were undertaken up to two years earlier, and are therefore not randomised in order, the comparison is still of interest. Because the untreated results quoted here are the means of eight rather than 12 subjects, they are similar but not identical to those already reported. The results on cimetidine alone and pancreatin plus cimetidine were compared with those on pancreatin alone as these three regimens were randomised in order. Results from our study of 14 healthy subjects ${ }^{20}$ have also been included where relevant.

\section{COMPARISON OF PH POOLS ON PANCREATIN} ALONE (Table 1)

$p H$

A mean of $49 \%$ of the PEG added to the meal was aspirated in total over the three hour test period on pancreatin. Of this, $60 \%$ was aspirated at $\mathrm{pH}<5$, significantly more than at $\mathrm{pH}>6$, and considerably 
Table 1 Pancreatin-comparison of pH pools

\begin{tabular}{|c|c|c|c|c|}
\hline & $p H<5$ & pH 5-6 & $p H>6$ & $\begin{array}{l}\text { Significance } \\
p H<5 \text { vs } p H>6\end{array}$ \\
\hline PEG recovery (\% total aspirated) & $59 \cdot 8 \pm 10 \cdot 5$ & $24 \cdot 5 \pm 6 \cdot 9$ & $15 \cdot 7 \pm 6 \cdot 8$ & $\mathrm{p}<0.05$ \\
\hline Lipid recovery (\% total aspirated) & $59 \cdot 4 \pm 9 \cdot 5$ & $21 \cdot 0 \pm 5 \cdot 8$ & $19 \cdot 7 \pm 7 \cdot 3$ & $\mathrm{p}<0.05$ \\
\hline PEG $(g / 1)$ & $8 \cdot 2 \pm 2 \cdot 4$ & $7 \cdot 0 \pm 0 \cdot 8$ & $5 \cdot 2 \pm 1 \cdot 0$ & NS \\
\hline Trypsin (IU/ml) & $2 \cdot 9 \pm 0 \cdot 9$ & $4 \cdot 3 \pm 1 \cdot 0$ & $14 \cdot 4 \pm 9 \cdot 2$ & $\mathrm{p}<0 \cdot 10$ \\
\hline Lipase (U/l) & $8 \cdot 6 \pm 4 \cdot 1$ & $20 \cdot 5 \pm 3 \cdot 8$ & $44 \cdot 9 \pm 21 \cdot 5$ & $\mathrm{p}<0.05$ \\
\hline Total lipid (mM/l) & $40 \cdot 9 \pm 14 \cdot 8$ & $25 \cdot 3 \pm 2 \cdot 5$ & $36 \cdot 0 \pm 9 \cdot 2$ & NS \\
\hline Total fatty acid (mM/l) & $2 \cdot 8 \pm 0 \cdot 6$ & $4 \cdot 0 \pm 0 \cdot 7$ & $7 \cdot 2 \pm 0 \cdot 9$ & $\mathrm{p}<0.05$ \\
\hline Lipolysis (\%) & $10 \cdot 8 \pm 2 \cdot 0$ & $19 \cdot 2 \pm 2 \cdot 8$ & $24 \cdot 2 \pm 5 \cdot 2$ & $\mathrm{p}<0 \cdot 05$ \\
\hline Total bile acid $(\mathrm{mM} / \mathrm{l})$ & $8 \cdot 7 \pm 1 \cdot 6$ & $13 \cdot 9 \pm 1 \cdot 6$ & $19 \cdot 4 \pm 2 \cdot 3$ & $\mathrm{p}<0 \cdot 10$ \\
\hline Aqueous phase bile acid (mM/l) & $3 \cdot 5 \pm 0 \cdot 6$ & $12 \cdot 6 \pm 1 \cdot 5$ & $18 \cdot 8 \pm 3 \cdot 3$ & $\mathrm{p}<0.05$ \\
\hline Bile acid precipitation $(\%)$ & $58 \cdot 6 \pm 5 \cdot 7$ & $9 \cdot 7 \pm 3 \cdot 1$ & $6 \cdot 7 \pm 7 \cdot 1$ & $\mathrm{p}<0.05$ \\
\hline Aqueous phase lipid (mM/l) & $4 \cdot 2 \pm 0 \cdot 6$ & $8 \cdot 6 \pm 0 \cdot 9$ & $13 \cdot 5 \pm 1 \cdot 9$ & $\mathrm{p}<0.05$ \\
\hline Aqueous phase fatty acid $(\mathrm{mM} / \mathrm{l})$ & $0 \cdot 8 \pm 0 \cdot 2$ & $3 \cdot 4 \pm 0 \cdot 6$ & $8 \cdot 1 \pm 0 \cdot 8$ & $\mathrm{p}<0.05$ \\
\hline Proportion fatty acid in aqueous phase (\%) & $41 \cdot 6 \pm 11 \cdot 3$ & $89 \cdot 3 \pm 14 \cdot 3$ & $116 \cdot 8 \pm 9 \cdot 1$ & $\mathrm{p}<0 \cdot 05$ \\
\hline
\end{tabular}

* Wilcoxon's signed ranks test.

more than on no treatment ( $45 \% \mathrm{NS})$; a similar increase was observed for the proportion of lipid aspirated at $\mathrm{pH}<5$ (Table 2 ). The proportions of lipid aspirated at each $\mathrm{pH}$ paralleled those of PEG, suggesting that the pH-effects described below applied equally to the aqueous and lipid portions of the meal. Polyethylene glycol concentrations did not vary significantly with $\mathrm{pH}$, although the trend to increased values at low $\mathrm{pH}$ would suggest that significant reductions in concentrations of other substances at $\mathrm{pH}<5$ were not because of differences in meal dilution.

\section{Pancreatic enzymes}

Activities of both trypsin and lipase increased with $\mathrm{pH}$, showing the effect of enzyme inactivation at $\mathrm{pH}<5$. For trypsin, the $\mathrm{pH}<5$ value $(2.9 \mathrm{IU} / \mathrm{ml})$ exceeded $10 \%$ of the overall mean $(18 \mathrm{IU} / \mathrm{ml})$ in our healthy subjects ${ }^{20}$ and the $\mathrm{pH}>6$ value $(14.4 \mathrm{IU} / \mathrm{ml})$ fell within our normal range (12-23 IU/ml). For lipase the $\mathrm{pH}<5$ value $(8.6 \mathrm{U} / \mathrm{l})$ failed to achieve $10 \%$ of our normal mean $(170 \mathrm{U} / \mathrm{l})$ and the $\mathrm{pH}>6$ value $(44.9 \mathrm{U} / \mathrm{l})$ was well below our normal range (100-240 U/1).

\section{Lipid digestion}

Total lipid concentrations did not vary significantly with $\mathrm{pH}$. Total fatty acid concentrations and lipolysis increased with $\mathrm{pH}$; the $\mathrm{pH}<5$ values were similar to the overall means on no treatment (Table 2), but the $\mathrm{pH}>6$ values were similar to the overall means in our healthy subjects (total fatty acid $8.2 \mathrm{mM} / \mathrm{l}$ and lipolysis $26 \%$ in health).

\section{Bile acids}

Total bile acid concentrations were similar to those on no treatment; similarly, half of the available bile acid was precipitated at $\mathrm{pH}<5$ while the value for bile acid precipitation at $\mathrm{pH}>6$ was not significantly different from zero. This resulted in a marked $\mathrm{pH}$-gradient for aqueous phase bile acid concentration similar to that observed on no treatment.

\section{Lipid solubilisation}

Both aqueous phase lipid and fatty acid concentrations showed a marked increase with $\mathrm{pH}$. The $\mathrm{pH}<5$ value for fatty acid was similar to that on no treatment $(1.1$ vs $0.8 \mathrm{mM} / \mathrm{l}$, NS), whereas the $\mathrm{pH}>6$ value was considerably higher $(8.1$ vs $3.0 \mathrm{mM} / \mathrm{l}$, $\mathrm{p}<0.05)$. The proportion of fatty acid in the aqueous phase also showed a marked $\mathrm{pH}$-gradient similar to that on no treatment.

\section{COMPARISON OF OVERALL MEANS ON EACH REGIMEN (Table 2) \\ Pancreatin alone}

Significant concentrations of trypsin and lipase were detected on pancreatin, but only trypsin achieved $10 \%$ of the mean value in health. Nevertheless there was a small but significant increase in both lipolysis and total fatty acid concentration in comparison with no treatment. Pancreatin did not reduce bile acid precipitation or increase aqueous phase bile acid concentration. As a result, although aqueous phase fatty acid concentration rose significantly, aqueous phase lipid concentration did not; it was significantly lower on pancreatin than on no treatment.

\section{Cimetidine alone}

All the aspirate was at $\mathrm{pH}>6$ on treatment with cimetidine. Trypsin was undetectable, as on no treatment, and lipase activities remained minimal. Lipolysis and total fatty acid concentrations were significantly lower than on pancreatin alone. Total bile acid concentration was similar to that on 


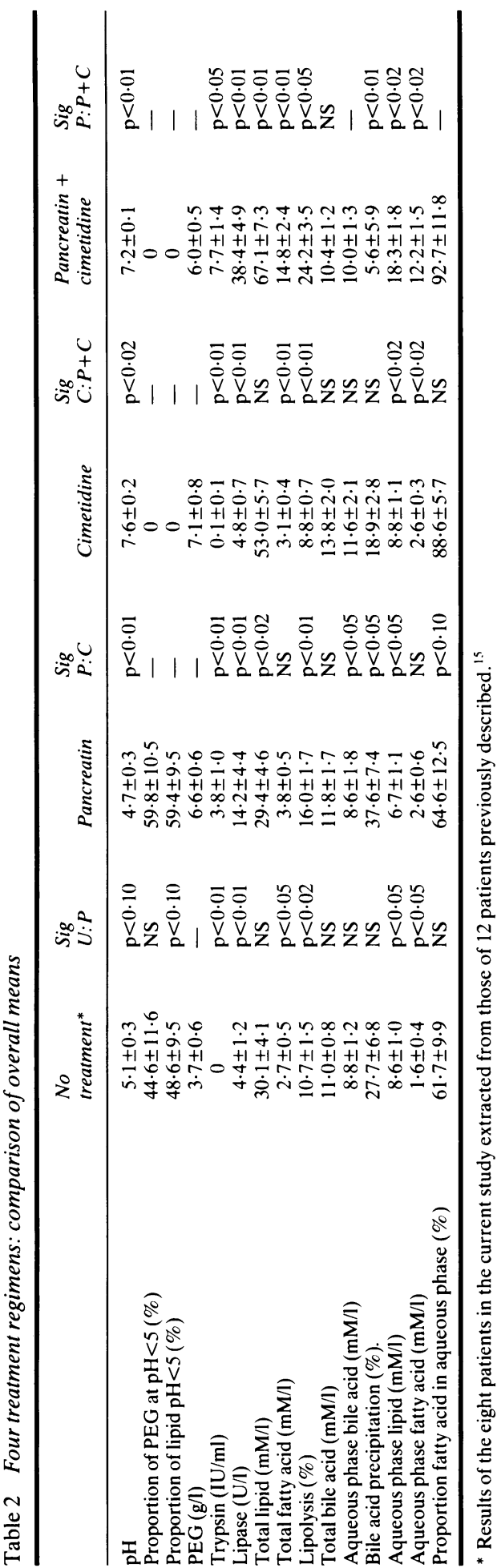


pancreatin alone, but bile acid precipitation was greatly reduced, resulting in an increase in aqueous phase bile acid concentration. Despite the reduced lipolysis, this improvement was associated with a small but significant increase in aqueous phase lipid concentration and in the proportion of fatty acid in the aqueous phase.

\section{Cimetidine plus pancreatin}

All aspirate was at $\mathrm{pH}>6$. Trypsin and lipase were markedly higher than on pancreatin alone, the trypsin concentration being almost $50 \%$, and lipase $25 \%$, of the normal mean. Lipolysis increased markedly compared with pancreatin alone, achieving a concentration similar to that observed in our healthy subjects $(26 \%)$. Total fatty acid concentration increased even further $(14.8 \mathrm{vs} 8.2 \mathrm{mM} / 1$ in health) attributable to higher total lipid concentration $(67.1$ vs $36.9 \mathrm{mM} / \mathrm{l}$ in health). There was a further, but not significant, reduction in bile acid precipitation almost to zero, but no associated increase in aqueous phase bile acid concentration. Aqueous phase lipid and fatty acid concentrations increased markedly to values more than twice those on pancreatin alone, and above those achieved in health (lipid 18.3 vs $9.6 \mathrm{mM} / \mathrm{l}$ in health, fatty acid $12.2 v s 4.8 \mathrm{mM} / \mathrm{l}$ ), again attributable to supranormal total lipid and fatty acid concentrations.

COMPARISON OF HOURLY POOLS (Tables 3 and 4 ) On both cimetidine regimens the proportion of lipid aspirated in the third hour was significantly less than that aspirated in the first hour (Table 3) or than in the third hour on pancreatin or no treatment (Table 4). No such differences were observed for the aqueous portion of the meal. Although the study

Table 3 Hourly meal recovery on each regimen - lipid and aqueous portions

\begin{tabular}{|c|c|c|c|c|}
\hline & 1st hour & 2nd hour & 3rd hour & $\begin{array}{l}\text { Significance } \\
1 \text { st \& } 3 r d^{*}\end{array}$ \\
\hline \multicolumn{5}{|c|}{ Lipid recovery (\% of total aspirated) } \\
\hline No treatment & $27 \pm 4$ & $30 \pm 3$ & $43 \pm 3$ & NS \\
\hline Pancreatin & $31 \pm 5$ & $39 \pm 4$ & $29 \pm 5$ & NS \\
\hline Cimetidine & $52 \pm 10$ & $38 \pm 8$ & $10 \pm 5$ & $\mathrm{p}<0.05$ \\
\hline $\begin{array}{r}\text { Pancreatin }+ \\
\text { cimetidine }\end{array}$ & $51 \pm 8$ & $34 \pm 6$ & $15 \pm 4$ & $\mathrm{p}<0.05$ \\
\hline \multicolumn{5}{|c|}{ PEG recovery (\% of total aspirated) } \\
\hline No treatment & $46 \pm 9$ & $34 \pm 7$ & $20 \pm 6$ & NS \\
\hline Pancreatin & $40 \pm 9$ & $38 \pm 8$ & $22 \pm 5$ & NS \\
\hline Cimetidine & $40 \pm 8$ & $42 \pm 6$ & $18 \pm 6$ & NS \\
\hline $\begin{array}{r}\text { Pancreatin }+ \\
\text { cimetidine }\end{array}$ & $33 \pm 8$ & $38 \pm 5$ & $28 \pm 7$ & NS \\
\hline
\end{tabular}

* By Friedmann analysis of variance by ranks and Wilcoxon's critical range test.
Table 4 Lipid recovery in each hour-regimens compared

\begin{tabular}{lll}
\hline 3rd hour & Cimetidine (10\%) & $\begin{array}{l}\text { Cimetidine }+ \\
\text { pancreatin (15\%) }\end{array}$ \\
\hline $\begin{array}{lll}\text { No treatment (43\%) } \\
\text { Pancreatin (29\%) }\end{array}$ & $\begin{array}{l}\mathrm{p}<0.01 \\
\mathrm{p}<0.01\end{array}$ & $\begin{array}{l}\mathrm{p}<0.01 \\
\mathrm{p}<0.02\end{array}$ \\
& Cimetidine (52\%) & $\begin{array}{l}\text { Pancreatin }+ \\
\text { cimetidine (51\%) }\end{array}$ \\
1st hour & $\mathrm{NS}$ & $\mathrm{p}<0.05$ \\
\hline No treatment $(27 \%)$ & $\mathrm{p}<0.05$ & $\mathrm{NS}$ \\
\hline Pancreatin $(31 \%)$ & & \\
\hline
\end{tabular}

was not designed to measure the rate of gastric emptying, these findings suggest that treatment with cimetidine, with or without pancreatin, corrects the delay in gastric emptying of lipid suggested by our study of untreated cystic fibrosis subjects. ${ }^{15}$ This may explain the higher total lipid concentrations on both cimetidine regimens, particularly in the first hour (not shown).

\section{Discussion}

This study has shown the effects of gastroduodenal neutralisation on each of the three $\mathrm{pH}$-dependent processes we suggested might limit the therapeutic response to pancreatin in cystic fibrosis: intragastric enzyme inactivation, and intraduodenal bile acid precipitation and fatty acid protonation. Duodenal neutralisation was achieved by the use of cimetidine $400 \mathrm{mg}$ and sodium bicarbonate $2 \mathrm{~g}$. The bicarbonate was probably superfluous, as on both cimetidine regimens jejunal $\mathrm{pH}$ remained above $7 \cdot 0$ and gastric $\mathrm{pH}$ above 6.0. In patients with chronic alcoholic pancreatitis, sodium bicarbonate $2.5 \mathrm{~g}$ alone did not control gastroduodenal $\mathrm{pH}$, but cimetidine $300 \mathrm{mg}$ did. ${ }^{24}$ From now on, therefore, we will refer to the effect of cimetidine rather than that of cimetidine plus bicarbonate. The results of our study can be analysed to show the contribution of each $\mathrm{pH}$ dependent process separately.

The contribution of enzyme inactivation and its prevention is shown by the pancreatin alone and pancreatin + cimetidine regimens. Treatment with pancreatin alone resulted in small but significant increases in overall mean trypsin, lipase, lipolysis and total fatty acid concentration over no treatment (Table 2). These changes occurred in the $\mathrm{pH}>6$ pools (Table 1), where enzyme activities on pancreatin alone were well above the $10 \%$ of the mean values in health shown to be necessary for normal absorption, ${ }^{11}$ and achieved a total fatty acid concentration and lipolysis similar to those in our healthy subjects. ${ }^{20}$ This suggests that acid mediated inactiva- 
tion in the stomach, and in duodenal samples of $\mathrm{pH}<5$ which constituted $60 \%$ of the meal, was responsible for the inadequate mean enzyme activities and lipolysis on pancreatin alone. It also indicates that seven Pancrex V capsules (a modest dose in our patients) would be sufficient to restore normal digestion were it not for this inactivation. The addition of cimetidine, by abolishing the $\mathrm{pH}<5$ and $\mathrm{pH}$ 5-6 samples, prevented this inactivation and led to a major improvement in enzyme activities to levels well above the minimum level required for normal fat absorption. It also achieved a level of lipolysis and total fatty acid concentration commensurate with our healthy subjects.

The Mayo Clinic study of patients with steatorrhoea caused by chronic alcoholic pancreatitis ${ }^{24}$ (reported since we started this study) also showed an improvement in enzyme activities with addition of cimetidine to pancreatin. The authors attributed this improvement to prevention of intragastric inactivation, and also to inhibition of gastric volume secretion and thus reduced dilution of intestinal contents. ${ }^{25}$ In our study, the similarity in lipase and trypsin activities, and in PEG concentration, between the cimetidine + pancreatin regimen (Table 2) and the $\mathrm{pH}>6$ pool on pancreatin alone (Table 1 ), suggests that it was only the prevention of inactivation that was responsible for this effect of cimetidine.

The effect of bile acid precipitation and its prevention is shown by the pancreatin alone and cimetidine alone regimens. On pancreatin alone overall bile acid precipitation and aqueous phase bile acid concentration were no better than on no treatment, as $60 \%$ of the meal was at $\mathrm{pH}<5$ (Table $2)$. The $\mathrm{pH}$-gradient for aqueous phase lipid and fatty acid concentration, and for the proportion of fatty acid in the aqueous phase, confirm that bile acid precipitation at $\mathrm{pH}<5$ continues to limit lipid solubilisation at this $\mathrm{pH}$ (Table 1), just as it does in untreated patients. ${ }^{15}$ This explains the failure of pancreatin alone to improve lipid solubilisation despite its effect in increasing lipolysis. Cimetidine alone, on the other hand, halved bile acid precipitation and increased aqueous phase bile acid concentration. This led to a small but significant increase in aqueous phase lipid concentration, despite lipase activity and lipolysis significantly lower than on pancreatin alone (Table 2). Furthermore, at $\mathrm{pH}>6$ on pancreatin alone, bile acid precipitation was minimal and, with the improved lipolysis, aqueous phase lipid and fatty acid concentrations approached those on the combined regimen.

The cimetidine alone results thus separate the effect of preventing bile acid precipitation from that of preventing enzyme inactivation; both prove to be important in improving lipid solubilisation. The Mayo Clinic studies ${ }^{24}{ }^{26}$ also showed that cimetidine prevents both processes, but were unable to show the separate contributions of each to improved lipid solubilisation. This distinction is important: while appropriate formulation of pancreatin preparations might avoid inactivation of their enzyme content, only postprandial duodenal neutralisation can prevent bile acid precipitation and fatty acid partitioning. Furthermore, the use of heat to inactivate lipase in the Mayo Clinic studies increases lipolysis ${ }^{20} 27$ and might therefore have artefactually exaggerated the differences between treatments.

The effect of fatty acid partitioning is shown by the pancreatin alone regimen. To separate fatty acid partitioning from bile acid precipitation in vivo is problematic because a reduction in $\mathrm{pH}$ affects both simultaneously. We used the mathematical approach explained in our study of lipid solubilisation in health ${ }^{20}$ to reveal a significant linear relationship between the proportion of fatty acid in the aqueous phase and bile acid precipitation (Fig. 2). The intercept of the regression line indicates that in the absence of bile acid precipitation, $90 \%$ of the fatty acid would be in the aqueous phase - a figure not significantly different from $100 \%$. In the presence of bile acid precipitation only $65 \%$ of the total fatty acid available was actually solubilised (Table 2 ). Most of this deficit in fatty acid solubilisation could therefore be attributed to bile acid precipitation and very little to fatty acid partitioning.

Treatment with pancreatin + cimetidine prevented both enzyme inactivation and bile acid precipitation, and greatly increased aqueous phase lipid and fatty acid concentrations to normal levels. ${ }^{20}$ The increase seems more than would be expected from the individual effects of enzyme inactivation and bile acid precipitation. Part of this 'synergistic' effect may be explained by the further fall in bile acid precipitation on addition of pancreatin to cimetidine (Table 2), to virtually zero. This may reflect reduced binding of bile acid to protein (appearing as 'precipitation' above $\mathrm{pH} \mathrm{6})^{28}$ due to improved proteolysis.

Our results show events at the duodenojejunal flexure. In health, $\mathrm{pH}$ rises to neutrality further down the intestine.$^{29}$ Bile acid precipitation (but not enzyme inactivation) is reversible in vitro by neutralisation of hyperacidic postprandial aspirate ${ }^{30}$ but it is not known if this would occur in vivo if hyperacidity were reversed. Postprandial ileal $\mathrm{pH}$ has not been investigated in cystic fibrosis, but is thought unlikely to rise ${ }^{26}$ as the abnormality in pancreatic bicarbonate secretion may well affect the small intestine. ${ }^{31}$ Patients with cystic fibrosis sometimes pass intact enteric coated pancreatin tablets in the 


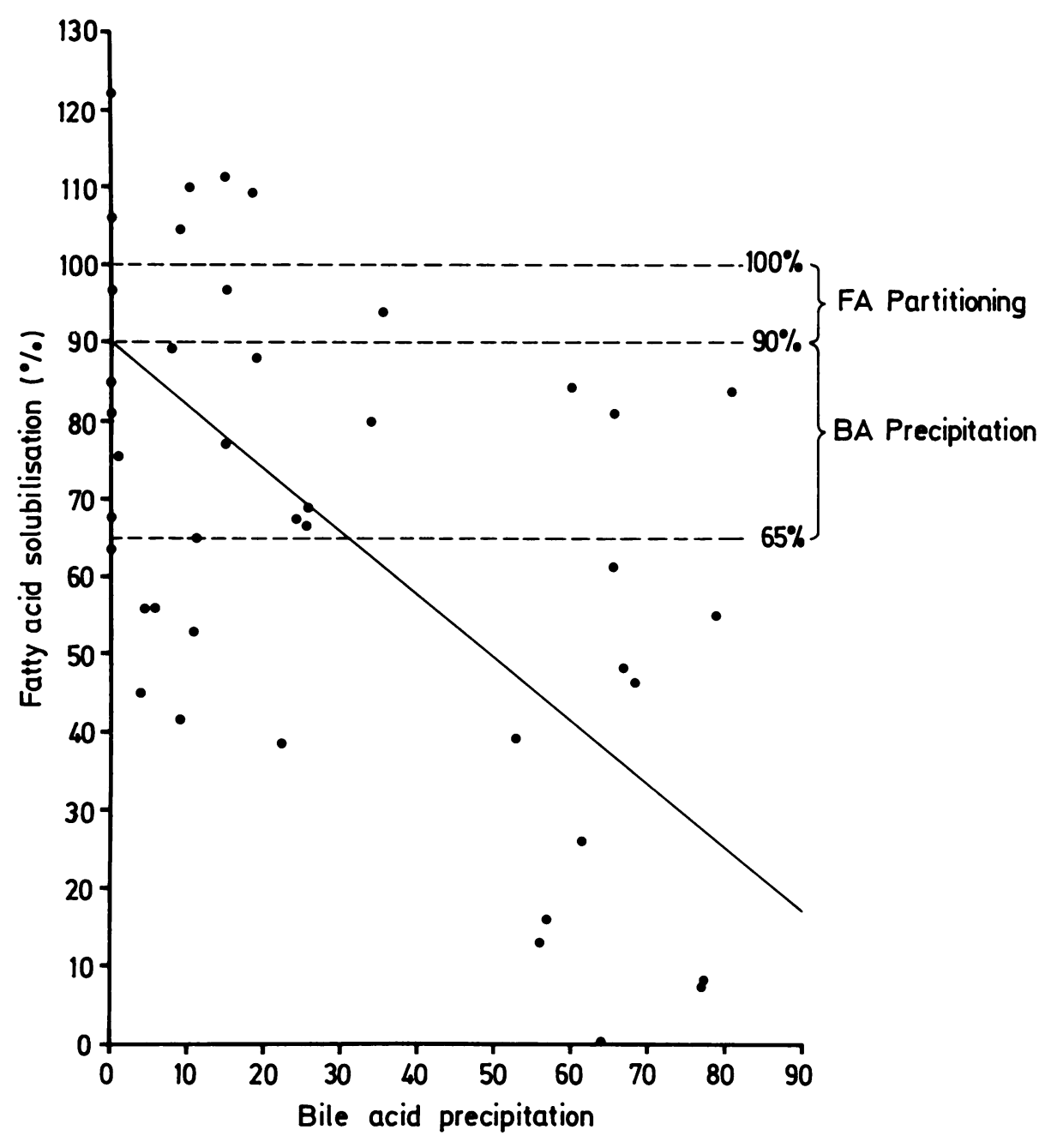

Fig. 2 Relationship between fatty acid solubilisation (adjusted for variation between individuals by analysis of covariance) and bile acid precipitation $(F=23 \cdot 7, p<0 \cdot 01$; intercept $90 \cdot 2 \pm 13 \cdot 6 \%)$.

stool, suggesting hyperacidity of the whole gut.

The results of our intraluminal study concur with those of several fat balance studies showing marked improvement in fat absorption with addition of cimetidine to pancreatin. ${ }^{24} 32-36$ Addition of an antacid does not achieve a comparable effect ${ }^{24} 37$ unless an unacceptably high dose is used. ${ }^{3}{ }^{32}$ As cimetidine's effect depends in part on preventing bile acid precipitation, its use is likely to prove worthwhile only in patients with jejunal hyperacidity and severe steatorrhoea - the patients likely to respond least well to enteric coated pancreatin.
This study was presented at the British Society of Gastroenterology Spring Meeting 1981 (Abstract Gut 1981; 22: A431).

We would like to thank the Cystic Fibrosis Trust for generously financing this project, Paines and Byrne Ltd for additional financial assistance and for the supply of specially formulated Pancrex V capsules, and Smith Kline and French Ltd for the supply of cimetidine and placebo. We are most grateful to Sister M E Gannon for nursing assistance, to $\mathrm{Mr} \mathrm{N}$ James for technical assistance, and to $\operatorname{Dr} M \quad R$ 
Boudry, PhD, for assistance in the computerised analysis of results.

\section{References}

1 Chase HP, Long MA, Lavin MH. Cystic fibrosis and malnutrition. J Pediatr 1979; 95: 337-47.

2 Hubbard VS, Dunn GD, Di Sant' Agnese PA. Abnormal fatty-acid composition of plasma lipids in cystic fibrosis. Lancet 1977; 2: 1302-4.

3 Weber AM, Roy CC, Chartrand L et al. Relationship between bile acid malabsorption and pancreatic insufficiency in cystic fibrosis. Gut 1976; 17: 295-9.

4 Goodchild MC, Murphy GM, Howell AM et al. Aspects of bile acid metabolism in cystic fibrosis. Arch Dis Child 1975; 50: 769-78.

5 Meyer JH. The ins and outs of oral pancreatic enzymes. $N$ Engl J Med 1977; 296: 1347-8.

6 Lapey A, Kattwinkel J, Di Sant'Agnese PA, Laster L. Steatorrhoea and azotorrhoea and their relation to growth and nutrition in adolescents and young adults with cystic fibrosis. J Pediatr 1974; 84: 328-34.

7 Davidson GP, Morad Hassel F, Crozier D, Corey M, Forstner GG. Iatrogenic hyperuricaemia in children with cystic fibrosis. J Pediatr 1978; 93: 976-8.

8 Nousia-Arvanitakis S. Stapleton FB, Linshaw MA, Kennedy J. Therapeutic approach to pancreatic-extract induced hyperuricosuria in cystic fibrosis. $J$ Pediatr 1977; 90: 302-5.

9 Heizer WD, Cleaveland CR, Iber FL. Gastric inactivation of pancreatic supplements. Bull Johns Hopkins Hosp 1965; 116: 261-70.

10 DiMagno EP, Malagelada J-R, Go VLW et al. Fate of orally ingested enzymes in pancreatic insufficiency. $N$ Engl J Med 1977; 296: 1318-22.

11 DiMagno EP, Go VLW, Summerskill WHJ. Relations between pancreatic enzyme outputs and malabsorption in severe pancreatic insufficiency. N Engl J Med 1973; 288: $813-5$.

12 Graham DY. Enzyme replacement therapy of exocrine pancreatic insufficiency in man. $N$ Engl J Med 1977; 296: $1314-7$.

13 Graham DY. An enteric-coated pancreatic enzyme preparation that works. Dig Dis Sci 1979; 24: 906-9.

14 Dutta SK, Russell RM, Iber FL. Impaired acid neutralisation in the duodenum in pancreatic insufficiency. Dig Dis Sci 1979; 24: 775-80.

15 Zentler-Munro PL, Fitzpatrick WJF, Batten JC, Northfield TC. Effect of intrajejunal acidity on aqueous phase bile acid and lipid concentrations in pancreatic steatorrhoea due to cystic fibrosis. Gut 1984; 25: $500-7$

16 Borgstrom B. Partition of lipids between emulsified oil and micellar phases of glyceride-bile salt dispersions. J Lipid Res 1967; 8: 598-608.

17 Dutta SK, Rubin J. Harvey J. Comparative evaluation of the therapeutic efficacy of a $\mathrm{pH}$-sensitive enteric coated pancreatic enzyme preparation with conventional pancreatic enzyme therapy in the treatment of exocrine pancreatic insufficiency. Gastroenterology 1983; 84: 476-82.
18 Gaskin KJ, Durie PR, Corey M, Wei P, Forstner GG. Evidence for a primary defect of pancreatic $\mathrm{HCO}_{3-}$ secretion in cystic fibrosis. Pediatr Res 1982; 16: 554-7.

19 Cox KL. Isenberg JN, Ament ME. Gastric acid hypersecretion in cystic fibrosis. J Pediatr Gastroenterol Nutr 1982; 1: 559-65.

20 Zentler-Munro PL, Fine DR, Fitzpatrick WJF, Northfield TC. Effect of intrajejunal acidity on lipid digestion and aqueous solubilisation of bile acids and lipids in health, using a new simple method of lipase inactivation. Gut 1984; 25: 491-9.

21 Watkins JB, Tercyak AM, Szczepanik P et al. Bile salt kinetics in cystic fibrosis: influence of pancreatic enzyme replacement. Gastroenterology 1977; 73: 1023-8.

22 Dowling RH, Mack E. Small DM. Effects of controlled interruption of the enterohepatic circulation of bile salts by biliary diversion and by ileal resection on bile salt secretion, synthesis and pool size in rhesus monkey. J Clin Invest 1970; 49: 232-42.

23 Saunders JHB, Drummond S, Wormsley KG. Inhibition of gastric acid secretion in treatment of pancreatic insufficiency. Br Med J 1977; 1: 418-9.

24 Regan PT, Malagelada J-R, DiMagno EP et al. Comparative effects of antacids, cimetidine and enteric coating on the therapeutic response to oral enzymes in severe pancreatic insufficiency. $N$ Engl J Med 1977; 297: 854-8.

25 Regan PT, Malagelada J-R, DiMagno EP, Go VLW. Rationale for the use of cimetidine in pancreatic insufficiency. Mayo Clin Proc 1978; 53: 79-83.

26 Regan PT, Malagelada J-R, DiMagno EP et al. Reduced intraluminal bile acid concentrations and fat maldigestion in pancreatic insufficiency: correction by treatment. Gastroenterology 1979; 77: 285-9.

27 Porter HP. Saunders DR. Isolation of the aqueous phase of human intestinal contents during the digestion of a fatty meal. Gastroenterology 1971; 60: 997-1007.

28 Lanzini A, Bird R, Fitzpatrick WJF et al. Bile acid binding to dietary protein. [Abstract] Gut 1981; 22: A 441 .

29 Borgstrom B, Dahlqvist A, Lundh G et al. Studies of intestinal digestion and absorption in the human. J Clin Invest 1957 ; 36: 1521-36.

30 Go VLW, Poley JR, Hofmann AF et al. Disturbances in fat digestion induced by acidic jejunal $\mathrm{pH}$ due to gastric hypersecretion in man. Gastroenterology 1970; 58: $638-46$.

31 Hadorn B, Johansen PG. Anderson CM. Pancreozymin-secretion test of exocrine pancreatic function in cystic fibrosis and the significance of the result for the pathogenesis of the disease. Canad Med Ass J 1968; 98: 377-85.

32 Durie PR, Bell L, Linton W, Corey ML, Forstner GG. Effect of cimetidine and sodium bicarbonate on pancreatic replacement therapy in cystic fibrosis. Gut 1980; 21: 778-86.

$33 \mathrm{Cox} \mathrm{KL}$, Isenberg JN, Osher $\mathrm{AB}$, Dooley RR. The effect of cimetidine on maldigestion in cystic fibrosis. J Paediatr 1979; 94: 488-92.

34 Boyle BJ, Long WB, Balistreri WF. Widzer SJ, Huang $\mathrm{N}$. Effect of cimetidine and pancreatic enzymes on serum and faecal bile acids and fat absorption in cystic 
fibrosis. Gastroenterology 1980; 78: 950-3.

35 Hubbard VS, Dunn GD, Lester LA. Effectiveness of cimetidine as an adjunct to supplemental pancreatic enzymes in patients with cystic fibrosis. Am J Clin Nutr 1980; 33: 2281-6.

36 Gow R, Bradbear R, Francis P, Shepherd R. Comparative study of varying regimens to improve steatorrhoea and creatorrhoea in cystic fibrosis: effectiveness of an enteric-coated preparation with and without antacids and cimetidine. Lancet 1981, 2: 1071-4.

37 Kattwinkel J, Agus SG, Taussig LM, Di Sant' Agnese PA, Laster L. The use of L-arginine and sodium bicarbonate in the treatment of malabsorption due to cystic fibrosis. Pediatrics 1972; 50: 133-7. 